
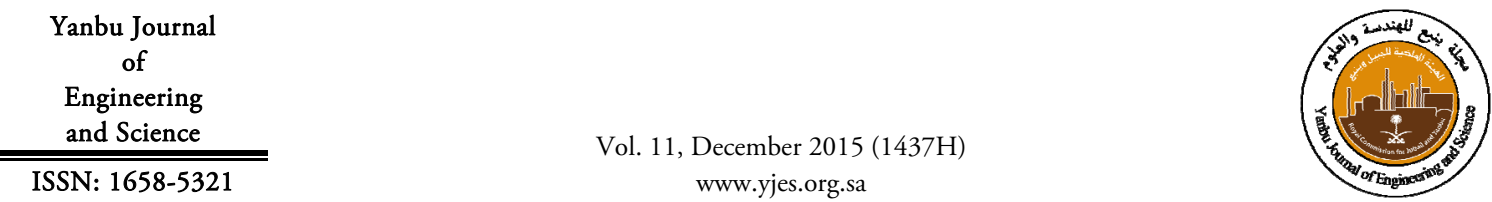

\title{
OPTIMUM PERCENTAGE OF VOLCANIC TUFF IN CONCRETE PRODUCTION
}

\author{
Mohmd Sarireh \\ Department of Civil Engineering, Tafila Technical University, Jordan \\ Email:m.sarireh@gmail.com,m.sarireh@ttu.edu.jo
}

\begin{abstract}
The Tafila area (Jabal Al Hala) is covered with volcanic tuff, which has been tested and studied for its possible use as a construction material in the production of ordinary concrete. The volcanic tuff material was used at 10, 20, 30, 40, and 50\% mix proportion of the materials in the concrete mix.It was subsequently tested for density, compressive strength, and flexural strength. The density of volcanic concrete (VC) ranged from 2195 to $2297 \mathrm{~kg} / \mathrm{m}^{3}$. At $20 \%$ of volcanic tuff or volcanic aggregate (VA), the density of VC was $2285 \mathrm{~kg} / \mathrm{m} 3$ and $2310 \mathrm{~kg} / \mathrm{m}^{3}$, the compressive strength was $17 \mathrm{MPa}$ and $21 \mathrm{MPa}$, flexural strength was $5 \mathrm{MPa}$ at the $7^{\text {th }}$ and $28^{\text {th }}$ days, respectively. The results showed that the volcanic tuff can be used in concrete production by replacing part of the aggregate (fine and coarse) by the VA, with the proportion of $20 \%$ of VA as the optimal value. The VA can be used for VC production where lower density is required for loading, and the $\mathrm{VC}$ shows a remarkable density and strength during the testing and construction at sites.
\end{abstract}

Keywords: Volcanic Aggregate (VA), Volcanic Concrete (VC), Volcanic Tuff.

\section{INTRODUCTION}

The concrete and related industrial constructs are the most common material used in the construction in Jordan. These materials are available in the form of different resources, such as crushed limestone in Karak and Tafila area, and rounded and volcanic tuff found in the Tafila area. The analysis of density, compressive strength, and flexural strength are the basic tests to determine the performance, measurements, and indicators for the construction materials in order to be selected and used for concrete production. The diversity in resources of aggregates and materials for construction gives variety for the concrete mix depending on the required property and performance. The high density, high strength, lightweight, and low strength concretes are required for different purposes at the construction sites. The improvements are required throughout the production stages, including the fresh and hardened states of concrete.

The current research aims at determining the optimum point in using volcanic tuff in concrete production. The volcanic concrete (VC) could be used in the construction of architectural details, linings, and walls that do not require high strength concrete, such as beams, columns, and bearing walls with or without the use of white stones.

The volcanic tuff had been obtained from AlHala mountains of Tafila area in the Southern part of Jordan that is $200 \mathrm{~km}$ to the South of Amman. Figure (1) presents the X-ray diffraction (XRD) spectra for the volcanic tuff used in the concrete mix in the current research. 


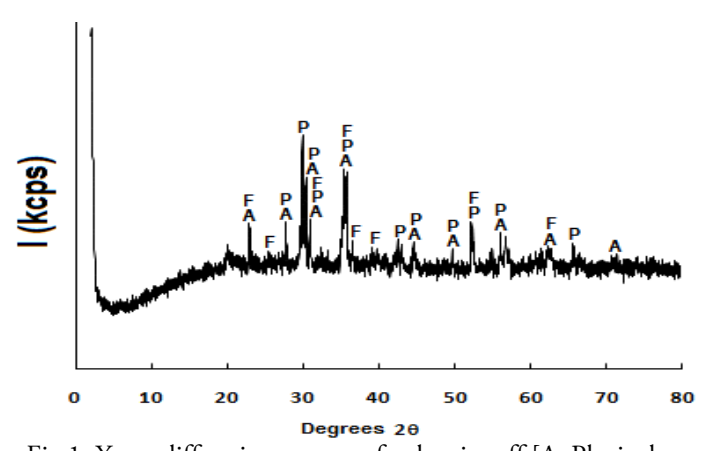

Fig.1. X-ray diffraction spectra of volcanic tuff.[A: Plagioclase feldspar (Anorthite), F: Olivine (Forsterite) and P: Pyroxene

(Augite)], Analysis in Royal Scientific Society Labs (April, 2014)

Table 1: Chemical Composition of VolcaniC TUFF. ANALYSIS IN ROYAL SOCIETY LABS (APRIL, 2014)

\begin{tabular}{|c|c|c|c|c|c|c|c|c|}
\hline \multicolumn{7}{|c|}{ Description: Volcanic tuff } \\
\hline $\begin{array}{c}\text { April / } \\
2014\end{array}$ & $\mathrm{MgO}^{2}$ & $\mathrm{Fe}_{2} \mathrm{O}_{3}$ & $\mathrm{TiO}_{2}$ & $\mathrm{SiO}_{2}$ & $\mathrm{CaO}_{2}$ & $\mathrm{~K}_{2} \mathrm{O}$ & $\mathrm{P}_{2} \mathrm{O}_{5}$ & $\mathrm{Al}_{2} \mathrm{O}_{3}$ \\
\hline $\begin{array}{c}\text { Result } \\
(\%)\end{array}$ & 9.55 & 13.42 & 3.94 & 35.64 & 9.56 & 0.77 & 0.71 & 10.45 \\
\hline
\end{tabular}

Table 1 represents the chemical composition of volcanic tuff used in the concrete production, and Table (2) represents the percentage of water content in the natural sample.

Cobanoglu et al. (2003) have tested and studied the engineering properties of the Sandikiziolithic tuffs that are found in the Western parts of Central Anatolia in Turkey. The study also investigated the possibility of using tuffs in concrete production. The concrete samples were prepared and tested for28 days in order to examine the physicmechanical properties of the tuff aggregates in concrete used as lightweight aggregates. The results of the study are promising to the limit to use tuffs as lightweight aggregate for the production of lightweight concrete.

Tupco and Uygunoglu (2010) used the volcanic tuff and dolomite aggregates, in addition to the pumice and limestone aggregates, in the production of concrete.

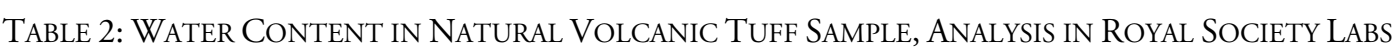
(APRIL, 2014)

\begin{tabular}{|c|c|c|c|c|c|c|c|c|}
\hline Date & $\begin{array}{c}\text { Mass of Can } \\
(\mathrm{g})\end{array}$ & $\begin{array}{c}\text { Total Mass } \\
\text { Wet }(\mathrm{g})\end{array}$ & $\begin{array}{c}\text { Total Mass } \\
\text { Dry }(\mathrm{g})\end{array}$ & $\begin{array}{c}\text { Wet Mass } \\
(\mathrm{g})\end{array}$ & $\begin{array}{c}\text { Dry Mass } \\
(\mathrm{g})\end{array}$ & $\begin{array}{c}\text { Water Mass } \\
(\mathrm{g})\end{array}$ & $\begin{array}{c}\text { \% Water } \\
\text { Content }\end{array}$ & $\begin{array}{c}\text { Average Water } \\
\text { Content\% }\end{array}$ \\
\hline \multirow{2}{*}{$4 / 2014$} & 3.006 & 122.83 & 115.99 & 119.8 & 112.9 & 6.84 & 5.70 \\
\cline { 2 - 8 } & 3.00 & 151.99 & 142.84 & 148.9 & 139.8 & 9.15 & 6.14 \\
\hline
\end{tabular}

The cement content was taken constant, but different combinations of water to binder ratio and plasticizers dosage were prepared for the mixes. The following properties were studied: 1) Physical properties including thermal conductivity, dry unit weight, porosity, and capillarity; and 2) Mechanical properties including compressive and splitting tensile strength, modulus of elasticity, and abrasion resistance were measured in the hardened stages. The results showed that the hardened, self-consolidated concrete with lightweight aggregate in lower unit weight exhibited lower mechanical and physical properties except for the thermal properties when compared to the properties of selfconsolidated concrete.

Abali et al.(2006) addressed the usage of the waste of volcanic tuff, in addition to the waste of the tincal waste, fly ash, and bentonite as a cement admixture. The authors examined the following properties that included 1)setting time, 2)expansion, 3)water requirement, 4) specific surface, and 5) compressive strength of the cement mixtures. The results stated that the early compressive strength decreased with increasing tincal waste and increasing initial setting time of the cement. The tincal waste and volcanic tuff of cement mixtures increased, whereas the compressive strength decreased. With the increase in the tincal waste, the retardation also increased. The initial setting time may be attributed to the high $\mathrm{B}_{2} \mathrm{O}_{3}$ and $\mathrm{MgO}$ content. The employment of volcanic tuff increased the compressive strength and decreased the initial setting time. 
Papadakis and Tsimas (2002) discussed that volcanic tuff and other fine materials, such as fly ash, silica fumes, and slag, exhibited cementaceous properties when blended into the concrete mix. These materials could be considered as additional cementaceous agents with different physical and chemical properties because of the variations that make the development and renewability viable in the design and construction. The performance of concrete mixes and the resultant compressive strength was compared to the quality of the cement. Moreover, a high volume of natural pozzolan $(50 \%$ of total fine cementateous materials) was used in concrete mix for structure application. Other two additional mixes with a high-volume of lowcalcium fly ash and granulated blast-furnace slag were also prepared for comparison between the mixes used in performance. In addition to the conventional Portland cement, the concrete mix was prepared as a reference and for comparison basis. The dosage required for a high-range waterreducing admixture for a given slump, air content, setting time, compressive strength, splitting tensile strength, and resistance to chloride-ion penetration were determined for the mixes. The inception of results indicated that the high-volume of natural pozzolan concrete mixes were suitable for structural concrete applications with 1740 to $2030 \mathrm{psi}$ (12 to $14 \mathrm{MPa}$ ) and 4210 to 5510 psi (29 to $38 \mathrm{MPa})$ compressive strengths at 3 and 28 days, respectively (Uzal et al., 2004).

Rodriguez-Camacho and Uribe-Afif (2002) have discussed the role of natural pozzolan in concrete durability. The importance of application led to the further use of the pozzolanic cement in concrete production. The different pozzolan cement containing natural pozzolan were used in mixes and compared to type I, II, and V cement.
The pozzolanic activity, composition, susceptibi-lity to sulfate attack, and expansion of mortar were evaluated and studied. It was noticed that the pozzolan cement with high activity and low alumina content had improved resistance to sulfate attack. Hence, the amount of pozzolan used in the cement is considered to be important.

Turanli et al. (2005) also highlighted the effect of the usage of natural pozzolan $(35,45$, and $55 \%$ ) on the properties of the blended cement paste and mortar. The blended cement of $450 \mathrm{~m}^{2} / \mathrm{kg}$ fineness was produced from the Turkish volcanic tuff in the laboratory mill through the inter-grinding of Portland cement clinker with natural pozzolan and gypsum. The cement tests applied are as follows: particle size distribution, setting time, heat of hydration, compressive strength, alkali-silica activity, sulfate resistance, $\mathrm{Ca}(\mathrm{OH})_{2}$ content, and XRD analysis for the crystalline hydration products. The compressive strength of the mortars made with blended cement containing large amounts of natural pozzolan was lower than that of the Portland cement at all tested ages up to 91 days. The blended cement containing large amounts of pozzolan exhibited much less expansion with respect to Portland cement in accelerated alkali-silica test and 36-week sulfate immersion test.

Gennaro etal. (2005) have tested the applicability of using the Italian zeolitizedvolcanoclastites for the production of lightweight aggregates in the industrial construction. The aggregate used with pozzolan had a low density of 0.9-1.1 $\mathrm{gm} / \mathrm{cm}^{3}$ (lightweight-expanded aggregate) to produce lightweight concrete. The aggregate tests included grain size analysis, lose weight, the mean density of the single grain, water absorption after $30 \mathrm{~min}$ and $24 \mathrm{~h}$, and particle strength. Subsequently, the light weight 
aggregates were mixed with sand, cement, and water to prepare concrete cubes to determine the unit weight and compressive strength on the 28th day. The investigated measurements and properties were tested and compared to the trade material produced and sold in the Italy market.

Yasin etal. (2012) had studied the volcanic tuff as local material for construction. They used three different materials known as yellow, grey, and brown volcanic tuff. The effect of fine volcanic tuff on concrete strength was studied. The volcanic tuff was studied in terms of percentage ranging from 10 to $80 \%$ of the aggregate in the concrete mix by producing the concrete on four grades: 20, 30, 40 , and $50 \mathrm{MPa}$. The results showed that the use of grey and brown volcanic tuff (20\%)improved the strength by $10 \%$ while the use of yellow volcanic tuff (20\%) improved the strength by $15 \%$.

Yeginobali etal. (1998) have studied the usage of natural lightweight aggregate in producing high strength concrete instead of special artificial aggregate with minerals and chemical admixtures. The replaced ingredients by the natural aggregate and admixtures can significantly reduce the cost of concrete production. The produced concrete strength from volcanic tuff and pumice concrete present the values of 30 and $16 \mathrm{MPa}$, respectively. The binding medium was produced by Portland cement, silica fume, and super-plasticizing mixtures. The concrete tests included workability, unit weight, compressive and splitting tensile strengths at various ages, modulus of elasticity, and thermal conductivity measures. The tests were conducted to touch the optimum proportions of quantities of the tested materials. The tests showed that a $55 \mathrm{MPa}$ of concrete could produce the required strength in 28 days by using a natural lightweight aggregate, and a dry unit weight in the range of 1700-2100 $\mathrm{kg} / \mathrm{m}^{3}$, in addition to the coefficient of thermal conductivity value of about 0.55 $\mathrm{W} / \mathrm{m}^{2} \mathrm{~K}$. Based on the experimental results, mathematical equations were analytically regressed and used for relating and optimizing concrete mixtures for specified unit weight and compressive strength.

The studies showed the ability to use volcanic tuff aggregate in the production of the concrete for architectural uses, lining for stone construction, partitions, and light decorations.

\section{RESULTS AND DISCUSSION}

The volcanic tuff aggregate had an apparent specific gravity of 2.24 and saturated surface dry specific gravity of 2.18 while the bulk specific gravity is 2.04 according to ASTM C127-84, ASTM C128-84, and ASTM C330-82a.

In relation to the gradation of the aggregate for ordinary control concrete and VC samples, Table (3) shows the gradation of the aggregate (coarse, medium, fine, and combined) according to the ASTM C 136-84. The concrete mix was designed to $20 \mathrm{Mpa}$ grade with the cement content of $308 \mathrm{~kg} / \mathrm{m}^{3}$, and water content of $185 \mathrm{~kg} / \mathrm{m}^{3}$ of the mix, and approximately 0.6 water/cement ratio. The aggregate was replaced by volcanic tuff aggregate at the ratios $10,20,30,40$, and $50 \%$.

The density of lightweight aggregate is an important property of the concrete that aims at the specific purpose of the construction (BS 1881: Part 107: 1983). Figure (2) represents the density of concrete using the volcanic tuff or volcanic lightweight aggregate (VLA) and fine materials at ratios of $10 \%$ to $50 \%$, by an increment of $10 \%$ for each patch of the mix. The results were obtained for the same at $7^{\text {th }}$ and $28^{\text {th }}$ days. 
Table 3: Sieve Analysis for Control Concrete Sample and VolCanic Tuff Concrete Samples

\begin{tabular}{|c|c|c|c|c|c|c|c|}
\hline \multirow{3}{*}{$\begin{array}{l}\text { Sieve Size (in.) } \\
\text { / No. }\end{array}$} & \multirow{3}{*}{ Sieve Size $(\mathrm{mm})$} & \multirow{3}{*}{$\begin{array}{c}\text { C.agg } \\
33 \% \\
\% \text { Pass } \\
\end{array}$} & \multirow{3}{*}{$\begin{array}{c}\text { M.agg } \\
33 \% \\
\% \text { Pass } \\
\end{array}$} & \multirow{3}{*}{$\begin{array}{l}\text { Sand } \\
34 \% \\
\% \text { Pass }\end{array}$} & \multirow{3}{*}{ Combined } & \multirow{2}{*}{\multicolumn{2}{|c|}{ Specification }} \\
\hline & & & & & & & \\
\hline & & & & & & Min. & Max. \\
\hline 1 & 25.4 & 100 & 100 & 100 & 100 & 90 & 100 \\
\hline $3 / 4 "$ & 19.0 & 95.3 & 100 & 100 & 98.4 & 70 & 100 \\
\hline $3 / 8^{\prime \prime}$ & 9.5 & 7.2 & 81.4 & 99.9 & 63.2 & 50 & 75 \\
\hline No. 4 & 4.8 & 1.1 & 26.8 & 99.5 & 43.0 & 35 & 60 \\
\hline No. 8 & 2.4 & 0.4 & 13.8 & 70.3 & 28.6 & 27 & 45 \\
\hline No. 16 & 1.2 & 0.3 & 12.2 & 63.4 & 25.7 & 20 & 35 \\
\hline No. 30 & 0.6 & 0.2 & 5.1 & 28.3 & 11.4 & 12 & 25 \\
\hline No. 50 & 0.3 & 0.2 & 2.7 & 19.5 & 7.6 & 5 & 15 \\
\hline No. 100 & 0.2 & 0.2 & 1.2 & 11.3 & 4.3 & 1 & 5 \\
\hline No. 200 & 0.1 & 0.1 & 0.5 & 3.8 & 1.5 & 0 & 5 \\
\hline
\end{tabular}

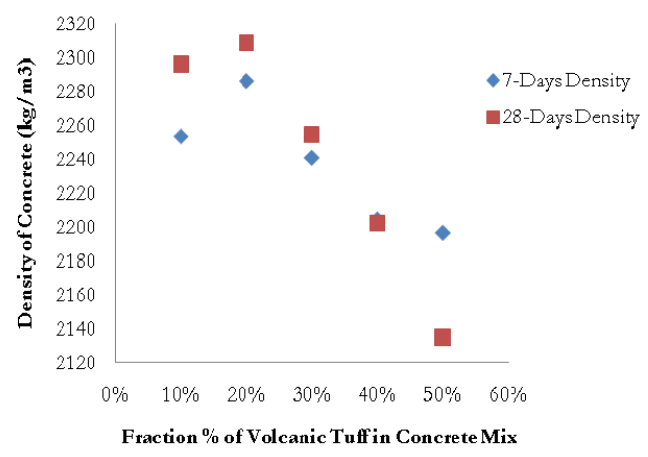

Fig.2. Density of volcanic lightweight concrete at 7-and 28-days

It is shown that the higher density is achieved at $20 \%$ of the volcanic aggregate (VA). At 7 day specimens' test, the density was found to be $2285 \mathrm{~kg} / \mathrm{m}^{3}$, and at 28-day specimens' test, it was $2310 \mathrm{~kg} / \mathrm{m}^{3}$.

The density of volcanic lightweight concrete (VLC) was also compared with the density of normal weight concrete. Figure (3) presents the density of VLC at 10,20,30,40, and $50 \%$ compared to the density of normal weight concrete at $7^{\text {th }}$ and $28^{\text {th }}$ days, respectively. It is obvious that the density of normal weight concrete is higher than the density of VLC for all proportions of VA. The density of normal concrete was found to be $2350 \mathrm{~kg} / \mathrm{m}^{3}$ at 7 -day specimens' test, and $2400 \mathrm{~kg} / \mathrm{m}^{3}$ at 28-days for the normal concrete. Compression strength of $\mathrm{VC}$ is another distinguishing property of the material.

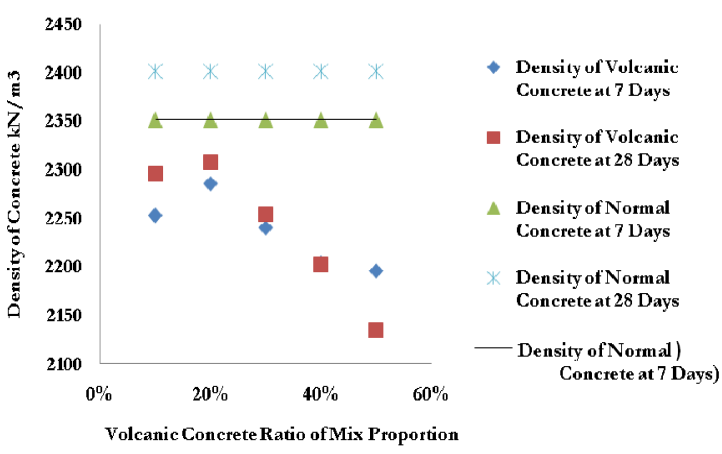

Fig.3. Comparison of density of volcanic concrete $\left(\mathrm{kN} / \mathrm{m}^{3}\right)$

Figure (4) presents the compression strength of $\mathrm{VC}$ on 7 and 28 days crushing test (BS 1881: Part 108: 1983). It is obvious that the compressive strength of VLC is optimum at $20 \%$ proportion of VA in the mix. The compressive strength of $\mathrm{VC}$ was found to be $17 \mathrm{MPa}$ at 7-day specimen's test and 20.5 $\mathrm{MPa}$ at 28-day specimen's test. In addition, the compressive strength is compared to that of the normal weight concrete.

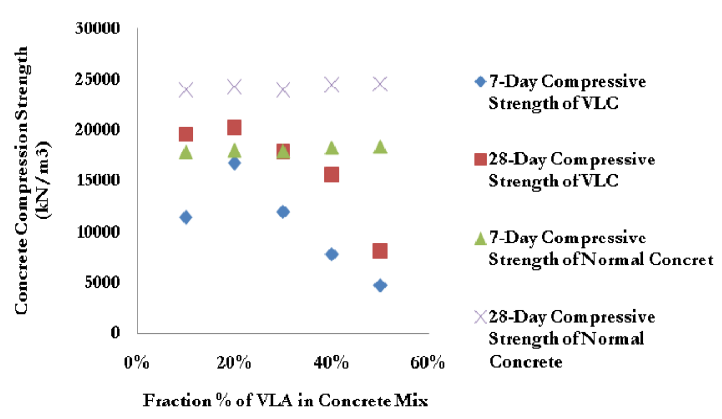

Fig.4. Compression Strength of Volcanic Concrete on 7 Days 


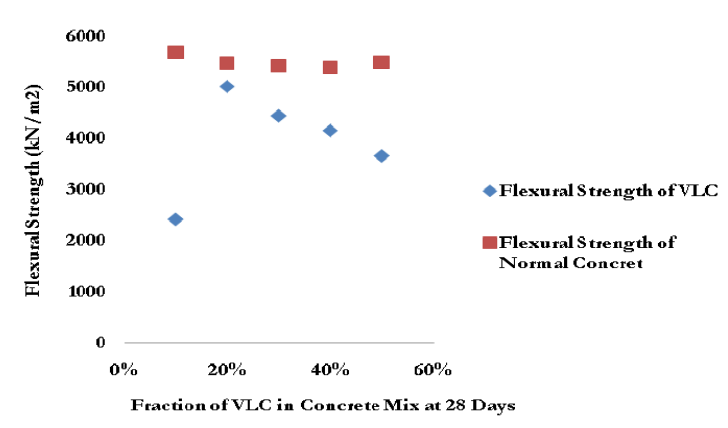

Fig.5. Flexural Beam of Volcanic Concrete $\left(\mathrm{kN} / \mathrm{m}^{3}\right)$

The flexural strength of volcanic lightweight concrete can be measured and evaluated to give a specific property of this material (BS 1881: Part 109: 1983). Figure (5) represents the flexural beam strength of VLC at 10, 20, 30,40 , and $50 \%$ proportion to normal aggregate. It is obvious that the flexural strength is the optimum at $20 \%$ proportion of the VLA, with a value of $5 \mathrm{MPa}$. In comparison to the flexural strength of normal weight concrete, it was obvious that it was higher for the last, and averaging at about 5.5 MPa. The use of natural pozzolan concrete mixes is considered suitable for structural concrete applications with 1740 to 2030 psi (12 to $14 \mathrm{MPa}$ ) and 4210 to 5510 psi $(29$ to $38 \mathrm{MPa}$ ) compressive strengths at $3^{\text {rd }}$ and $28^{\text {th }}$ days, respectively (Uzal et al., 2004). The produced VC in the current research at the optimum percentage $(20 \%)$ has the range of $2285-2310 \mathrm{~kg} / \mathrm{m}^{3}$ in density, and for compressive strength, the results obtained have the range of $16 \mathrm{Mpa}$ to $20 \mathrm{Mpa}$ at the $7^{\text {th }}$ and $28^{\text {th }}$ day, respectively.

Table 4: Permeability Test for Volcanic TufF CONCRETE VS. ORdinARY CONCRETE, TESTED AT ROYAL SCIENTIFIC SOCIETY LABS (2014)

\begin{tabular}{|c|c|c|c|}
\hline Sample ID & $\begin{array}{c}\text { Water } \\
\text { distance } \\
(\mathrm{cm})\end{array}$ & $\begin{array}{c}\text { Sample } \\
\text { high }(\mathrm{cm})\end{array}$ & $\begin{array}{c}\text { Pressure } \\
(\mathrm{KN})\end{array}$ \\
\hline Control B2 & 4 & 14.2 & 176 \\
\hline $10 \%$ Volcanic tuff & 4.8 & 14 & 163 \\
\hline $20 \%$ Volcanic tuff & 6.7 & 14.1 & 153 \\
\hline $30 \%$ Volcanic tuff & 11.9 & 14.3 & 86.7 \\
\hline
\end{tabular}

The normal concrete produced had the range of $2350-2400 \mathrm{~kg} / \mathrm{m}^{3}$ between the $7^{\text {th }}$ and $28^{\text {th }}$ day, respectively. While the compression strength obtained for normal concrete had the range of $18-24 \mathrm{Mpa}$ at the 7 the and $28^{\text {th }}$ day, respectively.

\section{PERMEABILITY TEST}

Permeability is another important property of concrete. Table (4) shows the permeability of 10,20 , and $30 \%$ volcanic tuff concrete compared to the control ordinary aggregate concrete sample. The results showed a reduction in pressure by $7.4,13.07$, and $50.74 \%$ related to the proportional mix of 10 , 20 , and $30 \%$ of volcanic tuff, respectively.

\section{CONCLUSION}

The current research presents the properties of $\mathrm{VC}$ by employing the VA in concrete mix in proportions of $10,20,30,40$, and $50 \%$. The physical tests, such as sieve analysis and specific gravity for both VA and normal weight aggregates (all specific gravities of VA that is less than those of normal weight aggregate) were conducted. Another physical test included the analysis of the density of hardened concrete, for both VC and normal weight concrete at $7^{\text {th }}$ and $28^{\text {th }}$ day. The results for VC density were lower than that of the normal weight concrete. This resulted in the use of low-density VC where structural concrete was not required. The mechanical tests (compression strength and flexural strength) were also applied on VC and normal weight concrete. The permeability test was conducted for the normal concrete and VC. The values obtained for $\mathrm{VC}$ were low for compressive and flexural strengths, and permeability compared to that of normal weight concrete. The VA showed remarkable properties of specific gravities, and the VC also showed remarkable density, compressive 
strength, and flexural strength, and permeability, which was low as compared to the normal concrete.

\section{ACKNOWLEDGEMENT}

I would like to thank the administration in Tafila Technical University: the presidency of the University, the Dean of the engineering college, the Dean of the academic research, and the colleagues in the department of civil engineering. My heartfelt thanks go to the engineers at Tafila Technical University for their help and support during the preparation and testing stage. I would like to thank my family: my wife, daughter, and sons for the time and the accommodate they offered me during the preparation and analysis of the work, and also during the writing and revision till the end.

\section{REFERENCES}

[1] Cobanoglu, Ibrahim, Ozpinar, Yahya, and Ozbek, Ahmet (2003). "Engineering properties of tuffs in the Sandikli region (Afyon-Turkey) and their possible use as concrete aggregates." Bulletin of Engineering Geology and the Environment, Vol. (62), Issue (4), Pages 369-378, November 2003.

[2] Tupco, IlkerBekir and Uygunoglu, Tyfun (2010) "Effect of aggregate type on properties of hardened self-consolidating lightweight concrete (SCLC)." Journal of Construction and Building Materials, Vol. (24), Issue (7), Pages (1286-1295), July 2010 .

[3] Abali, Y, S.U. Bayca, and S. Targan (2006). "Evaluation of blends tincal waste, volcanic tuff, bentonite and fly ash for use as a cement admixture." Journal of Hazardous Materials, Vol (131), Issue (1-3), Pages (126-130), 17 April 2006.

[4] V.G. Papadakis and Tsimas, S (2002)"Supplementary cementing materials in concrete: Part I: efficiency and design." Journal of Cement and Concrete Research, Vol (32), Issue (10), Pages 1525-1532, October 2002.
[5] BurakUzal, LutfullahTuranli, and P. Kumar Mehta . "High-Volume Natural Pozzolan Concrete for Structural Applications." International Concrete Abstracts Portal, ACI, Materials Journal, Vol. (104), Issue (5), Pages (535-538), 2007.

[6] R.E. Rodriguez-Camacho and R. Uribe-Afif (2002). "Importance of using the natural pozzolans on concrete durability." Journal of Cement and Concrete Research, Vol. (32), Issue (12), Pages (1851-1858), December 2002.

[7] L. Turanli, B. Uzal, and F. Bektas. "Effect of large amounts of natural pozzolanaddition on properties of blended cements." Journal of Cement and Concrete Research, Vol. (35), Issue (6), Pages (1106-11011), 2005.

[8] R. de Gennaro, P. Cappelletti, G. Gerri, M. deGennaro, M. Dondi, and A. Langella . "NeapolitanYellowTuffasrawmaterialforlightweig htaggregatesinlightweightstructuralconcreteprodu ction." Journal of Applied Clay Science, Vol. (28), Issue (1-4), Pages (309-319), 2005.

[9] Amjad A. Yasin, Mohammed T. Awwad, Hassan R. Hajjeh and Eid I. Sahawneh. "Effect of Volcanic Tuff on the Concrete Compressive Strength."Contemporary Engineering Sciences, Vol. (5), Issue (6), Pages (295 - 306), 2012.

[10] A. Yeginobali, K.G. Sobolev, S.V. Soboleva and M. Tokyay (1998). "High Strength Natural Lightweight Aggregate Concrete with Silica Fume." International Concrete Abstracts Portal, ACI, Vol. (176), Pages (739-759), 1998.

[11] ASTM C127-84. "Test for Specific Gravity and Absorption of Coarse Aggregate."

[12] 12. ASTM C128-84. " Test for Specific Gravity and Absorption of Fine Aggregate."

[13] ASTM C330-82a. "Specification for Lightweight Aggregates for Structural Concrete."

[14] BS 1881: Part 107: 1983. "Method for Determination of Density of Compacted Concrete."

[15] BS 1881: Part 108: 1983. "Method for Making Test Cubes from Fresh Concrete."

[16] BS 1881: Part 109: 1983. "Method for Making Test Beams from Fresh Concrete." 


\section{النسبة المثلى للطف البركاني في إنتاج الخرسانة}

محمد خليل الصر ايرة

جامعة الطفيلة التقنية، الأردن

الملخص:

يتو اجد الطف البركاني في منطقة الطفيلة في جبل الحلا، والمواد المفحوصة في الدراسة للنظرفي إمكانية استخدامها كمادة إنشائية في إنتاج الخرسانة العادية. و الطف البركاني المستخدم بنسب 10، 20، 30، 40، 50\% في مكونات الخلطة الخرسانية. وتم فحصها للكثافة، وقوة الكسر، وجهد الانحناء. وكانت كثافة الخرسانة من الطف البركاني تتر اوح من 2,195 إلى 2,297 كغم/م3 على 7 أيام، وكذلك كانت كثافة خرسانة الطف البركاني على نسبة 20\% من حصمة الطف البركاني في الخلطة 2,285 كغم/23، 2,310 كغم/23،على 28 يوم. وكانت قوة الكسر على نسبة 20\% لخرسانة الطف البركاني هي 17 ميجاباسكال على 7 أيام و 21 ميجاباسكال على 28-يوم. وكانت قوة العزم المفحوصة على نسبة 20\% نساوي 5 ميجاباسكال. النتائج تبين أنالطف البركاني يمكن استخدامه في إنتاج الخرسانة باستبدال جزء من الحصمة (ناعم وخشن) بحصمة الطف البركاني، ونسبة 20\% المستبدلة من حصمة الطف البركاني هي المتلى. حصمة الطف البركاني تستخدم في إنتاج الخرسانة بمختلف الكثافات بناء على الحمل في الأبنية، وخرسانة|لطف تعرض كثافة وقوة كسر معتبرة خلال الفحص و

$$
\text { الإنشاء في الموقع. }
$$

